\title{
Response to Knezevic et al: Reply from Manchikanti
}

\section{To The Editor:}

We read with interest the comment made by Knezevic et al in reference to the manuscript published by Ghai et al (1), but also the multiple manuscripts published Manchikanti et al (2-15). Manchikanti et al $(2,3)$, assessing the role of interlaminar and caudal epidural injections have shown that addition of steroids may be superior to local anesthetic alone with assessment of disability status at some of the follow-up periods. Though not robust, the major difference was a larger number of patients initially responding to the first 2 procedures when steroids were utilized in the disc herniation group (2). In the interlaminar trial 10 out of 60 patients were non-responsive in Group I with local anesthetic alone, whereas only one of 60 patients was non-responsive to local anesthetic with steroids (2). However, this difference was not seen with the caudal epidural trial (3). In addition with lumbar interlaminar, there were significant differences with pain rating and Oswestry Disability Index with significant improvement at 6 months. However, the significance of this difference was not demonstrated at 12 months and 24 months. Further, when only responsive patients were considered, there were no significant differences at all in either the lumbar or caudal trial. In the caudal trial there was also longer average relief per procedure with local anesthetic and steroids. This trial (3) also showed no significant differences in reference to proportion of patients with significant improvement. Such differences were not observed either with the caudal trial or lumbar interlaminar trials in managing pain of central stenosis or axial discogenic pain $(6,7,9,10)$. Further, with spinal stenosis there was no difference with unsuccessful patients in either group and also without outcomes either in the lumbar interlaminar trial or caudal trial. In fact, in discogenic pain patients fared better with local anesthetic alone $(5,6,10)$. Further, multiple manuscripts also have shown similar results with transforaminal, interlaminar, and caudal epidural injections in disc herniation (2,3,8,11-13). It may be of interest for Knezevic et al to know that in studying the role of caudal epidural injections, Manchikanti et al $(3,7)$ have compared local anesthetic with non-particulate betamethasone, local anesthetic with particulate betamethasone, and local anesthetic with particulate methylprednisolone with 20 patients in each study with a total of 60 patients in each group receiving steroids. There was no significant difference among the groups. Consequently, Manchikanti et al $(3,7)$ combined the results of 3 steroids as the overall steroid group.

In reference to the criticism of volume, there is no hard and fast rule of how much volume should be used. If there is an extensive filling pattern with $3 \mathrm{~mL}$ of contrast, obviously one needs to use a lesser total volume; whereas, if there is a poor filling pattern, one can use high volumes. Manchikanti et al chose $6 \mathrm{~mL}$ based on their own experiences; however, $8 \mathrm{~mL}$ may not be inappropriate or even $4 \mathrm{~mL}$ may not be inappropriate. Until we can prove that particulate steroids are superior to local anesthetic alone or local anesthetic with non-particulate steroids the discussion continues to be academic. It is also interesting that systematic reviews $(10-13,16)$ have shown similar results with local anesthetic alone compared to steroids and various approaches. Consequently, it is extremely difficult to identify the role of a ventral filling pattern. Thus far, there has not been any assessment of outcomes based on filling patterns. Further, even though generally it is assumed that that interlaminar epidural injections are midline, but the majority of the patients with unilateral pain are essentially parasagittal or paramedian injections. They tend to be parasagittal injections in many of the studies including those of Manchikanti et al, specifically in patients with unilateral pain. It is often difficult to obtain bilateral filling patterns even when the patients have bilateral pain with a midline approach as the needle tends to deviate to one side. Even with a slight deviation of the needle significant nerve root filling along with ventral filling is observed. It also has been an overall experience that even though there is significant nerve root filling as if it was administered by a transforaminal approach occasionally ventral filling is not observed. While we appreciate the analysis of outcomes by Candido et al (16) and also the various other comments, we are not quite certain about substantial differences with parasagittal interlaminar epidural injections since the majority of them are parasagittal, lateral, or paramedian injections which may not meet the definition of the authors for parasagittal, but provide the same results. Since a high proportion 
of patients have shown improvement in all the trials by Manchikanti et al in practical settings, it will be difficult to improve on the results but it is definitely feasible to replicate the results not only of Manchikanti et al but also of Candido et al and others.

\author{
Laxmaiah Manchikanti, MD \\ Clinical Professor of Anesthesiology and \\ Perioperative Medicine \\ University of Louisville, Louisville, Kentucky \\ Medical Director \\ Pain Management Center of Paducah \\ 2831 Lone Oak Road \\ Paducah, KY 42003 \\ E-mail: drlm@thepainmd.com
}

\section{References}

1. Ghai B, Kumar K, Bansal D, Dhatt SS, Kanukula R, Batra YK. Effectiveness of Parasagittal Interlaminar Epidural Local Anesthetic with or without Steroid in Chronic Lumbosacral Pain: A Randomized, Double-Blind Clinical Trial. Pain Physician 2015;18:237-248.

2. Manchikanti L, Singh V, Cash KA, Pampati V, Falco FJ. A randomized, doubleblind, active-control trial of the effectiveness of lumbar interlaminar epidural injections in disc herniation. Pain Physician 2014; 17:E61-E74.

3. Manchikanti L, Singh V, Cash KA, Pampati V, Damron KS, Boswell MV. Effect of fluoroscopically guided caudal epidural steroid or local anesthetic injections in the treatment of lumbar disc herniation and radiculitis: $A$ randomized, controlled, double blind trial with a two-year follow-up. Pain Physician 2012; 15:273286.

4. Manchikanti L, Cash KA, McManus CD, Damron KS, Pampati V, Falco FJ. A randomized, double-blind controlled trial of lumbar interlaminar epidural injections in central spinal stenosis: 2-year followup. Pain Physician 2015; 18:79-92.

5. Manchikanti L, Cash KA, McManus CD, Pampati V, Fellows B. Results of 2-year follow-up of a randomized, doubleblind, controlled trial of fluoroscopic caudal epidural injections in central spinal stenosis. Pain Physician 2012; 15: 371384 .

6. Manchikanti L, Cash KA, McManus CD, Pampati V, Benyamin RM. A random- ized, double-blind, active-controlled trial of fluoroscopic lumbar interlaminar epidural injections in chronic axial or discogenic low back pain: Results of 2-year follow-up. Pain Physician 2013; 16:E491E504.

7. Manchikanti L, Cash KA, McManus CD, Pampati V. Fluoroscopic caudal epidural injections in managing chronic axial low back pain without disc herniation, radiculitis or facet joint pain. J Pain Res 2012; 5:381-390.

8. Manchikanti L, Singh V, Pampati V, Falco FJE, Hirsch JA. Comparison of the efficacy of caudal, interlaminar, and transforaminal epidural injections in managing lumbar disc herniation: Is one method superior to the other? Korean J Pain 2015; 28:11-21.

9. Manchikanti L, Falco FJE, Pampati V, Hirsch JA. Lumbar interlaminar epidural injections are superior to caudal epidural injections in managing lumbar central spinal stenosis. Pain Physician 2014; 17:E691-E702.

10. Manchikanti L, Pampati V, Benyamin RM, Boswell MV. Analysis of efficacy differences between caudal and lumbar interlaminar epidural injections in chronic lumbar axial discogenic pain: Local anesthetic alone vs. local combined with steroids. Int ] Med Sci 2015; 12:214-222.

11. Manchikanti L, Nampiaparampil DE, Manchikanti KN, Falco FJ, Singh V, Benyamin RM, Kaye AD, Sehgal N, Soin A, Simopoulos TT, Bakshi S, Gharibo CG, Gilligan CJ, Hirsch JA. Comparison of the efficacy of saline, local anesthetics, and steroids in epidural and facet joint injections for the management of spinal pain: A systematic review of randomized controlled trials. Surg Neurol Int 2015; 6:S194S235.

12. Manchikanti L, Kaye AD, Manchikanti KN, Boswell MV, Pampati V, Hirsch JA. Efficacy of epidural injections in the treatment of lumbar central spinal stenosis: A systematic review. Anesth Pain Med 2015; 5:e23139.

13. Manchikanti L, Benyamin RM, Falco FJ, Kaye AD, Hirsch JA. Do epidural injections provide short- and long-term relief for lumbar disc herniation? A systematic review. Clin Orthop Relat Res 2015; 473:1940-1956.

14. Manchikanti L, Cash KA, McManus CD, Pampati $V$, Benyamin RM. Thoracic interlaminar epidural injections in managing chronic thoracic pain: A randomized, double-blind, controlled trial with a 2-year follow-up. Pain Physician 2014; 17:E327-E338.

15. Manchikanti L, Cash KA, Pampati V, Wargo BW, Malla Y. A randomized, doubleblind, active control trial of fluoroscopic cervical interlaminar epidural injections in chronic pain of cervical disc herniation: Results of a 2-year follow-up. Pain Physician 2013; 16:465-478.

16. Chang Chien GC, Knezevic NN, McCormick Z, Chu SK, Trescot Am, Candido KD. Transforaminal versus interlaminar approaches to epidural steroid injections: A systematic review of comparative studies for lumbosacral radicular pain. Pain Physician 2014; 17:E509-E524. 